\title{
Role of Lipopolysaccharide in Regulating Colony-Stimulating Factor-Dependent Macrophage Proliferation In Vitro
}

\author{
ROBERT N. MOORE,* PATRICIA S. STEEG, DANIELA N. MÄNNEL, AND \\ STEPHAN E. MERGENHAGEN \\ Laboratory of Microbiology and Immunology, National Institute of Dental Research, \\ Bethesda, Maryland 20205
}

\begin{abstract}
Bacterial lipopolysaccharides (LPS) enhance both production of colony-stimulating factors (CSF) and proliferation of mononuclear phagocytes in vivo. The present study was undertaken to determine whether the effects of LPS on CSFdependent monopoiesis are due solely to enhanced production of CSF or also to direct effects of LPS on the responding progenitor cell. Addition of LPS to CSFstimulated macrophage populations had different effects, depending upon the concentration of CSF in the cultures. In the presence of optimal to supraoptimal concentrations of CSF, LPS at doses $\geq 0.01 \mu \mathrm{g} / \mathrm{ml}$ inhibited macrophage colony formation. This inhibitory activity was not due to cytotoxicity of the LPS and was not mediated through prostaglandin synthesis. In the presence of suboptimal concentrations of CSF, minute concentrations of LPS $\left(10^{-7} \mu \mathrm{g} / \mathrm{ml}\right)$ significantly enhanced macrophage colony formation. Both effects of LPS (inhibition and enhancement) appeared to be properties of lipid A since neither effect was noted with cells from LPS-resistant $\mathrm{C} 3 \mathrm{H} / \mathrm{HeJ}$ mice, whereas both effects could be neutralized by the addition of the antibiotic polymyxin $B$, which binds to the lipid A portion of LPS. These results suggest that the effects of LPS on monopoiesis in vivo may not be due solely to its capacity to stimulate production of CSF. Rather, LPS may be involved in stimulating monopoiesis both indirectly through stimulation of CSF production and by its effects on the CSF-responsive progenitor cell.
\end{abstract}

Bacterial endotoxins and their lipopolysaccharide (LPS) moieties act on a variety of mammalian cell types (reviewed in reference 3 ). Of these cell types, monocytes and macrophages are perhaps the most sensitive to the effects of LPS. Teleologically, this is acceptable since these cells are the most likely to encounter either LPS or gram-negative bacteria in either endotoxemic or infected animals.

LPS has been shown to exert a variety of seemingly direct effects on macrophages. In extreme cases LPS can be cytotoxic for macrophages $(14,33,37)$. In a majority of experimental systems, however, LPS is stimulatory rather than lethal. This stimulation has been detected as enhancement of killing capacity $(1,10,47)$ and associated production of oxygen metabolites (32), secretion of proteolytic enzymes $(3,46)$, and production of a variety of soluble mediators $(13,23,24,26,27,43,45)$, including colony-stimulating factor (CSF; 12). CSF is a myeloproliferative agent $(4,5,34)$ that has the capacity to stimulate clonal proliferation and differentiation of macrophage precursors $(38,39)$. Both LPS $(6$, $8,21,35)$ and infection with gram-negative bacteria $(2,40)$ enhance serum CSF levels and stim- ulate myelopoiesis in vivo. In a previous report (28), we showed that LPS-induced production of CSF by macrophages is regulated by the concomitant production of $\mathrm{E}$ prostaglandins. In the present study, we have investigated the effect of LPS on CSF-induced cloning of macrophage precursor cells (39). Our findings show that LPS can exert different effects, depending upon the concentration of CSF present in the cultures. In the presence of optimal to supraoptimal concentrations of CSF, LPS inhibited macrophage colony formation in a noncytotoxic manner. In contrast, macrophage colony formation induced by suboptimal concentrations of CSF was enhanced by addition of minute amounts of LPS.

\section{MATERIALS AND METHODS}

Animals. Male $\mathrm{C} 3 \mathrm{H} / \mathrm{HeN}$ mice were obtained from the National Institutes of Health Division of Research Resources, Bethesda, Md. C3H/HeJ mice of both sexes were purchased from Jackson Laboratories, Bar Harbor, Maine. The animals were used at 6 to 8 weeks of age.

Reagents. LPS was extracted from Escherichia coli K-235 by the phenol-water method of McIntire et al. (25). LPS solutions were prepared fresh for each experiment by suspending the LPS at $1 \mathrm{mg} / \mathrm{ml}$ in 
$\mathrm{Ca}^{2+}$ - and $\mathrm{Mg}^{2+}$-free Hanks balanced salt solution (HBSS; Microbiological Associates, Walkersville, Md). Indomethacin and polymyxin B sulfate were purchased from Sigma Chemical Co. (St. Louis, Mo.). Appropriate dilutions of reagents in HBSS were added to the cultures in a volume of $0.1 \mathrm{ml}$. Conditioned medium (LCM) and column-fractionated CSF were prepared from $L$ cells by a modification of the method of Waheed and Shadduck (42). Mouse L cells (clone 929; Microbiological Associates) were grown in minimum essential medium (NIH Media Production Unit, Bethesda, Md.) supplemented with $5 \%$ fetal calf serum (Microbiological Associates) and antibiotics (50 U of penicillin and $50 \mu \mathrm{g}$ of streptomycin per $\mathrm{ml}$ ). Confluent monolayers of cells were trypsinized to remove the cells from their flasks. The cells were washed three times in HBSS and suspended at $3 \times 10^{5}$ to $5 \times 10^{5}$ cells per $\mathrm{ml}$ in serum-free medium 199 (NIH Media Production Unit) containing antibiotics. A total of 50 $\mathrm{ml}$ of cell suspension was then added to $75-\mathrm{cm}^{2}$ tissue culture flasks and incubated for 7 days at $37^{\circ} \mathrm{C}$ in a $5 \%$ $\mathrm{CO}_{2}$-in-air incubator. The supernatant medium was collected by centrifugation and stored frozen at $-20^{\circ} \mathrm{C}$. To prepare concentrated LCM, the medium was thawed and concentrated approximately 200 -fold in an ultrafiltration cell (Amicon Corp., Lexington, Mass.) with a PM-30 membrane. The concentrate was then dialyzed for 3 days against three 1,000-fold changes of distilled, deionized water containing $100 \mathrm{U}$ of penicillin and $100 \mu \mathrm{g}$ of streptomycin per $\mathrm{ml}$. The water-soluble portion was separated by centrifugation at $10,000 \times g$ and dialyzed against RPMI 1640 medium containing antibiotics. After sterilization by passage through 0.22 $\mu \mathrm{m}$ filters (Millipore Corp., Bedford, Mass.), the LCM was stored frozen at $-20^{\circ} \mathrm{C}$.

To obtain a CSF-enriched preparation, the LCM $(2 \mathrm{ml})$ was chromatographed at $4^{\circ} \mathrm{C}$ on a Sephacryl S200 (Pharmacia, Uppsala, Sweden) column (2.5 by 95 $\mathrm{cm})$ using reverse flow at a rate of approximately 12 $\mathrm{ml} / \mathrm{h}$. The buffer system used was $50 \mathrm{mM}$ tris(hydroxymethyl)aminomethane-hydrochloride ( $\mathrm{pH} \mathrm{7.5),}$ containing $0.1 \mathrm{M} \mathrm{NaCl}$, and 3-ml fractions were collected. The majority of the CSF was eluted in a range correlating with marker proteins having molecular weights of 100,000 to 150,000 . These fractions were pooled, concentrated to the original volume of LCM applied to the column, and dialyzed against RPMI 1640 plus antibiotics. The concentrate was then filter sterilized and stored frozen at $-20^{\circ} \mathrm{C}$.

Biological assays. CSF activity was determined in soft agar culture of bone marrow cells as previously described (28). Units of CSF activity represent the calculated colony yield in $1.0 \mathrm{ml}$ of sample and were determined from the linear portion of a dilution series.

Cloning of macrophage precursor cells was measured in liquid culture by a modification of the method described by Stewart and Lin (39). Thioglycolate-induced ( $2 \mathrm{ml}$ intraperitoneally, 3 days prior) peritoneal cells from $\mathrm{C} 3 \mathrm{H} / \mathrm{HeN}$ mice were suspended in enriched McCoy 5A medium (28) at $1 \times 10^{3}$ cells per $\mathrm{ml}$. A 2-m amount of this cell suspension was then placed in 35mm culture dishes (Falcon Division, Becton Dickinson \& Co., Cockeysville, Md.) along with a source of CSF with or without other reagents. The plates were then incubated at $37^{\circ} \mathrm{C}$ for 14 days in $5 \% \mathrm{CO}_{2}$-in-air atmos- phere. Colonies (proliferative centers of 25 cells or more) were scored with a dissecting microscope at $\times 30$ magnification. Colonies forming under these conditions were greater than $99 \%$ macrophages as judged by cell morphology, differential staining, and phagocytosis of antibody-coated sheep erythrocytes (41).

Direct visual assessment of proliferation and viability was made by microscopic observation of cells cultured in eight-chambered slides (Lab-Tek no. 4838; Lab-Tek Products, Div. Miles Laboratories Inc., Naperville, Ill.). Peritoneal exudate cells $\left(4 \times 10^{4}\right)$ in 0.4 $\mathrm{ml}$ of McCoy medium were added to each well and allowed to adhere for $2 \mathrm{~h}$ at $37^{\circ} \mathrm{C}$. After removal of nonadherent cells by washing, medium containing dilutions of LCM or LPS or both was returned to the cultures. At timed intervals the chambers were inspected with an inverted microscope at $\times 200$ magnification for cell numbers and for viability as measured by trypan blue exclusion (41). Based on randomly selected samples, both the primary and extended-term cultures were greater than $98 \%$ macrophages as judged by morphology, differential staining, and phagocytosis of antibody-coated sheep erythrocytes.

Statistical analyses. Comparisons of individual means were performed with the Student's $t$ test.

\section{RESULTS}

Inhibition of macrophage colony formation by LPS. Addition of LPS to LCM-stimulated adherent peritoneal exudate cells resulted in a dose-dependent inhibition of macrophage colony formation (Fig. 1). This inhibitory effect was most dramatic at supraoptimal dilutions of LCM and lessened, with lower doses of LPS (1.0 to $0.01 \mu \mathrm{g} / \mathrm{ml}$ ), as the dilution of LCM increased. LPS by itself did not cause clone formation in these cultures.

Absence of detectable cytotoxicity. Certain preparations of LPS have been shown to be cytotoxic for macrophages at relatively high con-

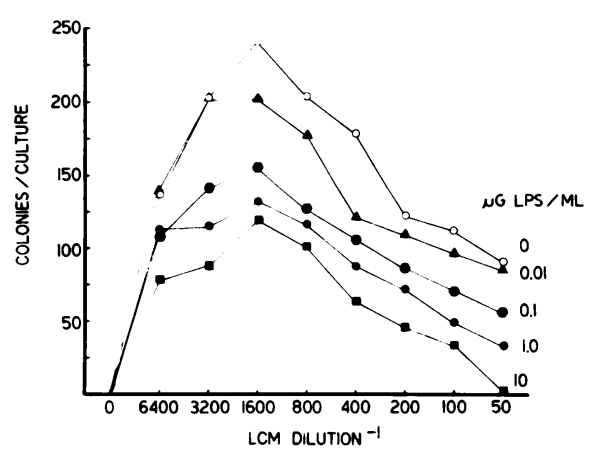

Fig. 1. Suppression by LPS of macrophage clone formation induced by LCM. Adherent peritoneal exudate cells from $2 \times 10^{3}$ total exudate cells were exposed to dilutions of LCM in the presence or ab. sence of LPS. Colonies were counted 14 days later, and values represent the mean colony count of triplicate cultures. 
centrations (14). Although the LPS preparation used in this investigation was chosen because it was not toxic for macrophages in vitro $(<5 \%$ kill after overnight incubation of thioglycolate-induced macrophages with $50 \mu \mathrm{g}$ of LPS per $\mathrm{ml}$ ), it was considered necessary to determine whether the LPS was inhibiting macrophage colony formation by killing the responding cells. A direct microscopic analysis was used to ascertain this point. Exudate cells were cultured in eight-well chamber slides in the presence of LCM and LPS. At timed intervals the medium was removed, and the cultures were observed for both viability, as measured by trypan blue exclusion, and for total cell numbers. As shown in Fig. 2A, the LPS alone did not exert any observable cytotoxic effect on any culture observed. The values shown in this figure represent viable cell numbers, which in all cases were $>98 \%$. In these control cultures, to which no LCM was added, there was an approximate twofold increase in cell numbers per field during the 10-day observation period. This increase was not significantly affected by the presence of up to 10 $\mu \mathrm{g}$ of LPS per ml. In control cultures treated with either a 1:100 (20,000 U of CSF) or 1:800 (2,500 U of CSF) dilution of LCM, a significant proliferative response was observed (Fig. $2 \mathrm{~B}$ and C), which was dramatically apparent by day 10 . In those cultures treated with 1:100 LCM (Fig. 2B), LPS exerted an inhibitory effect which was significantly different $(P \leq 0.05)$ from the control at day 7 . In these cultures little increase in cell numbers occurred between days 7 and 10 although there was no measurable increase in cell death. In cultures treated with 1:800 LCM (Fig. $2 \mathrm{C}$ ), an observable inhibition of proliferation was not apparent until day 10, and again the population remained greater than $98 \%$ viable. Based on these results, the inhibitory effect of LPS on
LCM-induced macrophage precursor division did not appear to be due to a direct cytotoxic effect of the LPS. The LPS appeared instead to exert a CSF-dose-dependent cytostatic effect.

Evidence that the inhibitory effect is associated with lipid A. Macrophages from the $\mathrm{C} 3 \mathrm{H} / \mathrm{HeJ}$ mouse have been shown to be either unresponsive or poorly responsive to a variety of effects elicited by LPS and the lipid A portion of LPS $(11,33,41,44)$. In this study, the exudate progenitor cells of this mouse strain also failed to respond to this inhibitory effect of LPS (Fig. 3A) at concentrations which are clearly inhibitory for the LPS-responsive $\mathrm{C} 3 \mathrm{H} / \mathrm{HeN}$ cells (Fig. 3B).

These results suggested that the inhibitory activity was mediated through lipid A. To test

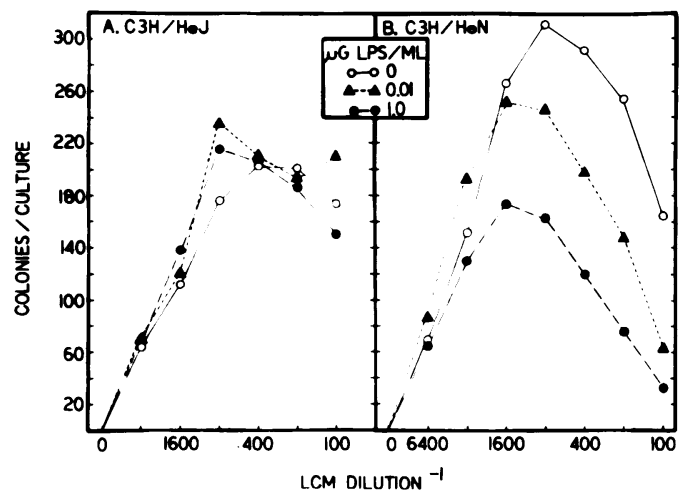

Fig. 3. Comparative effects of LPS on LCM-induced cloning of macrophage progenitor cells from $\mathrm{C} 3 \mathrm{H} / \mathrm{HeJ}(\mathrm{A})$ and $\mathrm{C} 3 \mathrm{H} / \mathrm{HeN}$ (B) mice. Values are colony counts after 14 days of incubation of adherent cells from $2 \times 10^{3}$ total thioglycolate-induced peritoneal exudate cells and represent means of triplicate cultures. The CSF activity of the undiluted LCM used was $2 \times 10^{6} \mathrm{U} / \mathrm{ml}$.

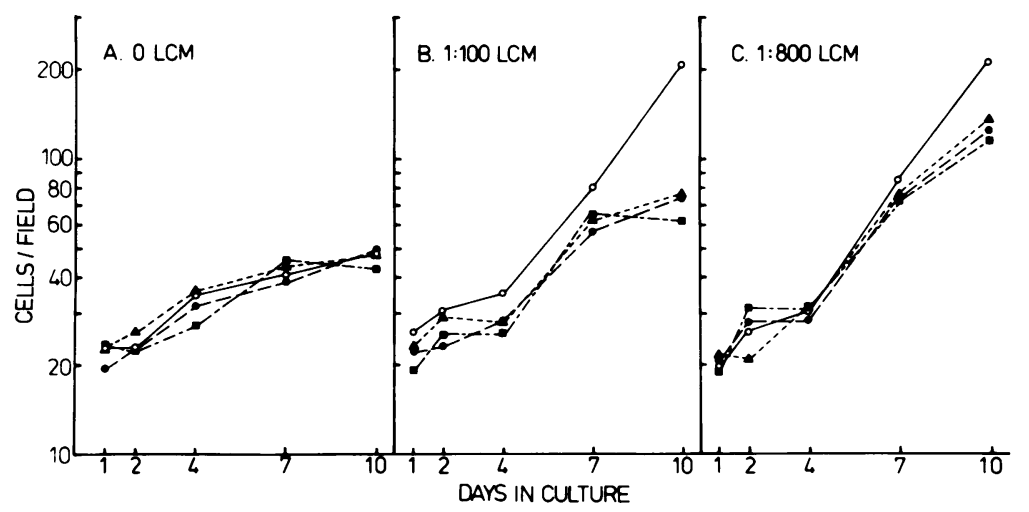

Fig. 2. Viable cell numbers per $\times 200$ microscope field at timed intervals after addition of LCM with or without LPS. Values represent means of five randomly selected fields and were greater than $98 \%$ viable at all points as measured by trypan blue exclusion. Symbols for LPS doses are as follows $(\mu \mathrm{g} / \mathrm{ml}): 0(0) ; 0.01(\Delta)$; $1.0(0) ; 10.0$ (口). LCM at 1:100 and 1:800 are 20,000 and 2,500 $U$ of CSF activity per ml, respectively. 
this possibility, the LPS preparation was pretreated with polymyxin $B$, which neutralizes LPS effects by forming a stable complex with the lipid A portion of the molecule (33). Addition of the antibiotic to the LPS blocked its inhibitory activity for the sensitive mouse strain (Table 1), providing further evidence that the inhibitory activity of LPS is a property of the lipid A moiety.

Effect of indomethacin on the inhibitory effect of LPS. Kurland and Moore (19) have recently shown that $\mathrm{E}$ prostaglandins inhibit CSF-induced cloning of both bone marrow and peritoneal exudate progenitor cells. Since both LPS $(18,43,44)$ and CSF (38) stimulate E prostaglandin production by macrophages, the possibility that these mediators might influence the cloning efficiency of progenitor cells in this study was investigated.

Adherent peritoneal exudate cells were exposed to different dilutions of LCM and LPS in the presence or absence of indomethacin, a potent inhibitor of the cyclooxygenase pathway of prostaglandin synthesis. The dose of indomethacin used $(1 \mu \mathrm{g} / \mathrm{ml})$ has been shown to be sufficient to block LPS-induced synthesis of prostaglandins by macrophages (28). As reported previously by Hadden et al. (16), addition of indomethacin to the cultures did have an enhancing effect on factor-induced colony formation (Fig. 4A). Indomethacin, however, failed to alter the inhibition of clonal proliferation effected by the addition of LPS (Fig. 4B). Prostaglandins, therefore, do not appear to play a major role in this inhibitory effect of LPS.

Enhanced cloning of macrophage progenitor cells with LPS and suboptimal concentrations of CSF. In several experiments, such as that shown in Fig. 2B, submicrogram

TABLE 1. Neutralization of the suppressive effect of LPS on macrophage colony formation by polymyxin $B$

\begin{tabular}{clcc}
\hline Units of $\mathrm{CSF}^{a}$ & $\begin{array}{c}\mathrm{LPS} \\
(\mu \mathrm{g} / \mathrm{ml})\end{array}$ & $\begin{array}{c}\mathrm{PB}^{b} \\
(\mu \mathrm{g} / \mathrm{ml})\end{array}$ & $\begin{array}{c}\text { No. of colonies } \\
\text { per culture } \pm \\
\text { SEM }^{c}\end{array}$ \\
\hline 2,500 & 0 & 0 & $179 \pm 5$ \\
2,500 & 1.0 & 0 & $82 \pm 3$ \\
2,500 & 0 & 10.0 & $164 \pm 15$ \\
2,500 & 1.0 & 10.0 & $192 \pm 31$ \\
0 & 1.0 & 0 & 0 \\
0 & 0 & 10.0 & 0
\end{tabular}

${ }^{a}$ Units of Sephacryl S-200 column-fractionated L cell-derived colony-stimulating activity per milliliter.

${ }^{b}$ Polymyxin B sulfate.

c Colony count 14 days after addition of CSF to 2 $\times 10^{3}$ thioglycolate-elicited $\mathrm{C} 3 \mathrm{H} / \mathrm{HeN}$ peritoneal exudate cells. Values represent means of triplicate cultures \pm standard error.

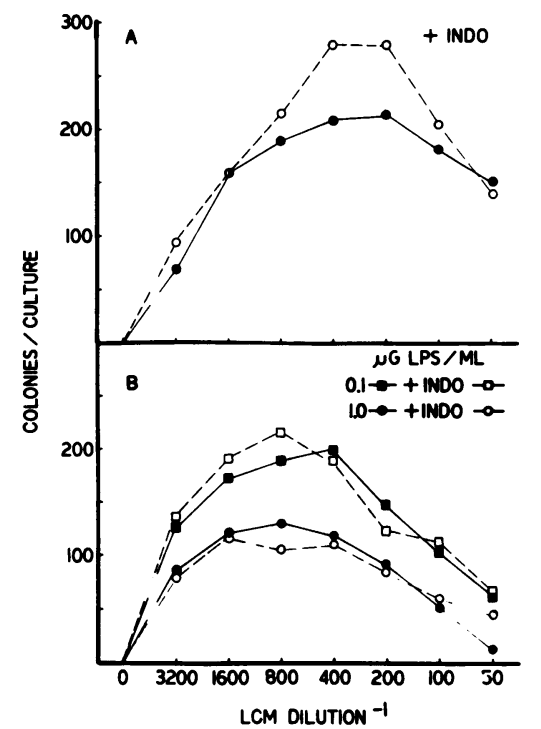

Fig. 4. Effect of indomethacin (INDO, $1 \mu \mathrm{g} / \mathrm{ml})$ on LCM-induced cloning of macrophage progenitor cells either in the absence $(A)$ or presence (B) of LPS. Values are colony counts after 14 days of incubation of adherent cells from $2 \times 10^{3}$ thioglycolate-induced peritoneal exudate cells and represent means of triplicate cultures. The CSF activity of the undiluted LCM used was $2 \times 10^{6} \mathrm{U} / \mathrm{ml}$.

doses of LPS enhanced, rather than inhibited, macrophage cloning stimulated by suboptimal doses of LCM. This suggested that under certain circumstances LPS might enhance the cloning of macrophage progenitor cells. Since recent studies have shown that crude CSF preparations might contain high-molecular-weight enhancers for CSF-induced cloning in vitro (M. Frolich, D. W. Golde, and M. J. Cline, J. Supramol. Struct., suppl. 3. 1979, abstr. no 648 , p. 255 ), the LCM was fractionated on a Sephacryl S-200 column to obtain the CSF-positive fractions free of both high- and low-molecular-weight contaminants. Results obtained with column-fractionated CSF are given in Fig. 5. In a dose-dependent manner, LPS could either suppress or enhance the cloning response of $\mathrm{C} 3 \mathrm{H} / \mathrm{HeN}$ macrophage progenitor cells, depending on the dose of CSF (Fig. 5A). The inhibitory effect of LPS was expressed at optimal and supraoptimal concentrations of CSF, whereas the enhancing effect was most obvious in the suboptimal to optimal CSF concentration range. Again, LPS had no significant effect on CSF-induced cloning of $\mathrm{C} 3 \mathrm{H} / \mathrm{HeJ}$ macrophage progenitors (Fig. 5B).

Results shown in Fig. 6 establish two main points regarding the enhancing effect of LPS on CSF-induced progenitor cell cloning. First, the progenitor cells are exquisitely sensitive to this 


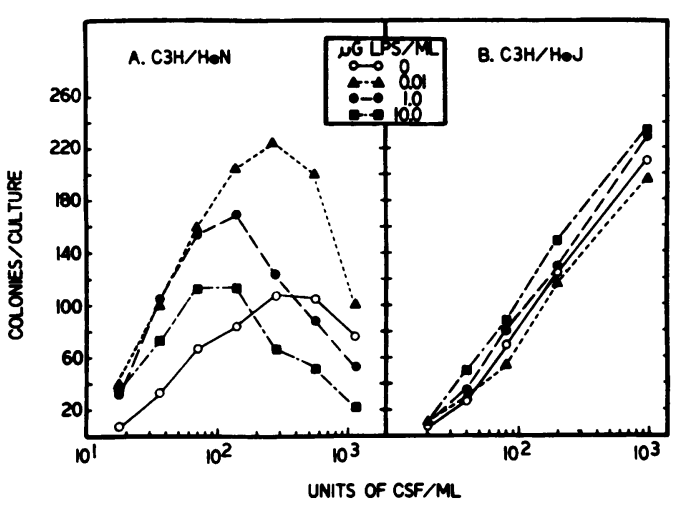

Fig. 5. Comparative effects of LPS on CSF-induced cloning of macrophage progenitor cells from $\mathrm{C} 3 \mathrm{H} / \mathrm{HeN}(\mathrm{A})$ and $\mathrm{C3H} / \mathrm{HeJ}(\mathrm{B})$ mice. The CSF preparation used was the pooled fractions of CSF activity obtained after gel filtration of LCM on Sephacryl S200. Values are colony counts after 14 days of incubation of adherent cells from $2 \times 10^{3}$ total thioglycolate-induced peritoneal exudate cells and represent means of triplicate cultures.

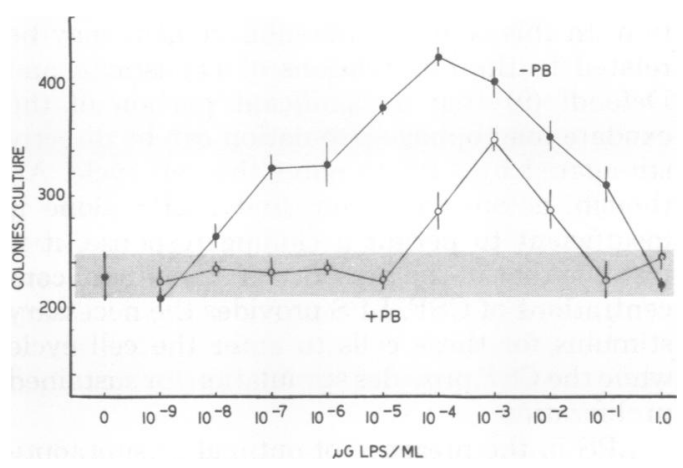

Fig. 6. Enhanced cloning of macrophage precursor cells exposed to LPS and $200 U$ of column-fractionated $L$ cell $C S F$ per $\mathrm{ml}$. Values represented by closed circles are means of triplicate cultures \pm one standard error, and values represented by open circles are similar means obtained from cultures incubated in the presence of polymyxin $B$ sulfate $(P B)$ at 10 times the concentration of each LPS dose used. The shaded area represents the mean \pm one standard deviation of the number of colonies formed in response only to $200 \mathrm{U}$ of CSF per $\mathrm{ml}$.

effect of LPS. In the presence of $200 \mathrm{U}$ of CSF, as little as $10^{-7} \mu \mathrm{g}$ of LPS per ml was sufficient to significantly enhance $(P \leq 0.05)$ the cloning response. Second, addition of polymyxin $B$ to the LPS at concentrations 10 times greater than each LPS dose was sufficient to totally neutralize the enhancing effect of LPS at LPS doses $\leq 10^{-4} \mu \mathrm{g} / \mathrm{ml}$. At LPS doses $>10^{-4} \mu \mathrm{g} / \mathrm{ml}$, polymyxin $B$ was able to partially neutralize the enhancing effect. Polymyxin $B$ at concentrations ranging from $10^{-8}$ to $10 \mu \mathrm{g} / \mathrm{ml}$ had no effect on macrophage cloning stimulated by $200 \mathrm{U}$ of CSF (data not shown). The reversal by polymyxin B (Fig. 6 and Table 1), combined with the failure of $\mathrm{C} 3 \mathrm{H} / \mathrm{HeJ}$ cells to respond to LPS (Fig. 5B), suggested that the enhancing effect of LPS, as well as the inhibitory effect noted at higher CSF concentrations, was due to lipid A.

Kinetics of the LPS effects. The preceding experiments established that LPS can either enhance or suppress CSF-induced cloning of macrophage progenitor cells, depending upon the concentration of CSF added to the cultures. The following experiments were designed to determine the effect of LPS when added before or after the addition of CSF.

Addition of LPS either $24 \mathrm{~h}$ before or after CSF had little effect on either the inhibitory or enhancing effect of LPS on the cloning response (Table 2). Addition of LPS delayed up to 6 days after CSF also had no effect on the inhibitory activity of LPS in the presence of either 2,500 or $20,000 \mathrm{U}$ of $\mathrm{CSF} / \mathrm{ml}$ (Table 3 ). In addition, delayed addition of LPS to slide-chamber cultures, although inhibiting proliferation, did not result in observable cell death (data not shown), supporting the contention that the inhibitory effect of LPS is not due to cytotoxicity. These results indicated that the inhibitory effect of LPS could be exerted on cells already undergoing a proliferative response to relatively high doses of CSF.

Enhanced cloning elicited by $0.001 \mu \mathrm{g}$ of LPS per $\mathrm{ml}$ was diminished when the LPS was added after CSF and was virtually gone when the LPS was added 6 days later (Table 3). The LPS was apparently influencing progenitor cells in a manner that allowed them to proliferate in response to suboptimal doses of CSF. Upon prolonged culture these cells gradually lost the capacity to respond to this effect of LPS.

\section{DISCUSSION}

Both LPS and infection with gram-negative bacteria have profound effects on myelopoiesis in vivo. Sublethal doses of LPS increase both serum CSF levels and numbers of mononuclear phagocytes and granulocytes $(6,8,21,35)$. LPS has also been found to increase the numbers of myeloid stem cells in cell cycle in treated animals (21). Animals infected with gram-negative bacteria, such as Salmonella typhimurium, also show a rapid increase in serum CSF and a subsequent increase in numbers of mononuclear phagocytes $(2,40)$. Additionally, it has been shown that increases in serum CSF after Xirradiation are associated with the presence of gram-negative bacteria in the intestinal tract (7), whereas conventionalization of antibiotic-pre- 
TABLE 2. Macrophage colony formation by exudate progenitor cells exposed to LPS or CSF at 0 or $24 h$

\begin{tabular}{|c|c|c|c|c|c|c|}
\hline \multirow{2}{*}{ Units of $\mathrm{CSF}^{a}$} & \multicolumn{2}{|c|}{ Addition to culture at: } & \multicolumn{4}{|c|}{ No. of colonies per culture ${ }^{h}$ at LPS dose $(\mu \mathrm{g} / \mathrm{ml})$ of: } \\
\hline & $0 \mathrm{~h}$ & $24 \mathrm{~h}$ & 0 & 1.0 & 0.01 & 0.0001 \\
\hline 1,000 & $\begin{array}{l}\text { CSF + LPS } \\
\text { CSF } \\
\text { LPS }\end{array}$ & $\begin{array}{l}-c \\
\text { LPS } \\
\text { CSF }\end{array}$ & $\begin{array}{l}233 \pm 9 \\
233 \pm 9 \\
264 \pm 24\end{array}$ & $\begin{array}{l}141 \pm 15 \\
168 \pm 14 \\
170 \pm 8\end{array}$ & $\begin{array}{l}- \\
- \\
-\end{array}$ & - \\
\hline 200 & $\begin{array}{l}\text { CSF + LPS } \\
\text { CSF } \\
\text { LPS }\end{array}$ & $\begin{array}{l}- \\
\text { LPS } \\
\text { CSF }\end{array}$ & $\begin{array}{r}111 \pm 8 \\
111 \pm 8 \\
84 \pm 6\end{array}$ & $\begin{array}{l}216 \pm 10 \\
222 \pm 9 \\
186 \pm 14\end{array}$ & $\begin{array}{l}248 \pm 5 \\
270 \pm 12 \\
228 \pm 6\end{array}$ & $\begin{array}{l}248 \pm 10 \\
254 \pm 16 \\
244 \pm 15\end{array}$ \\
\hline
\end{tabular}

a Units of Sephacryl S-200 column-fractionated L cell-derived colony-stimulating activity per milliliter.

${ }^{b}$ Colony count 14 days after addition of CSF to $2 \times 10^{3}$ thioglycolate-elicited $\mathrm{C} 3 \mathrm{H} / \mathrm{HeN}$ peritoneal exudate cells. Values represent means of triplicate cultures \pm one standard error.

c - None.

TABLE 3. Effect of delayed addition of LPS on macrophage colony formation by exudate progenitor cells exposed to LCM or Sephacryl S-200. fractionated CSF

\begin{tabular}{ccccc}
\hline \multirow{2}{*}{$\begin{array}{c}\text { Units of } \\
\mathrm{CSF}^{a}\end{array}$} & $\begin{array}{c}\text { LPS dose } \\
(\mu \mathrm{g} / \mathrm{ml})\end{array}$ & \multicolumn{3}{c}{$\begin{array}{c}\text { No. of colonies per culture at day of } \\
\text { LPS addition }\end{array}$} \\
\cline { 3 - 5 } & & \multicolumn{1}{c}{0} & \multicolumn{1}{c}{3} & \multicolumn{1}{c}{} \\
\hline $20,000^{c}$ & 0 & $201 \pm 11$ & $-^{d}$ & - \\
& 1.0 & $93 \pm 18$ & $89 \pm 3$ & $90 \pm 24$ \\
$2,500^{c}$ & 0 & $338 \pm 9$ & - & - \\
& 1.0 & $170 \pm 2$ & $178 \pm 5$ & $171 \pm 7$ \\
$200^{e}$ & 0 & $213 \pm 9$ & - & - \\
& 0.001 & $362 \pm 20$ & $307 \pm 37$ & $232 \pm 35$ \\
\hline
\end{tabular}

${ }^{a}$ Units of colony-stimulating activity added per culture.

${ }^{b}$ Colony count 14 days after addition of CSF to $2 \times 10^{3}$ thioglycolate-elicited $\mathrm{C} 3 \mathrm{H} / \mathrm{HeN}$ peritoneal exudate cells. Values represent means of triplicate cultures \pm one standard error.

' Units of LCM-CSF per milliliter.

$d-, 0$ LPS controi.

e Units of Sephacryl S-200 pool CSF.

treated canines resulted in an increase in plasma CSF and a marked increase in bone marrow stem cells (22). In all of these cases, it is implied that either LPS or other bacterial products are stimulating production of CSF which subsequently enhances proliferation of the myeloid progenitor cells. Results reported in this communication, however, provided evidence that the effects of LPS on myelopoiesis may not be mediated solely through production of CSF. Very small doses of LPS $\left(10^{-7} \mu \mathrm{g} / \mathrm{ml}\right)$ were found to significantly enhance cloning of exudate macrophage progenitor cells exposed to suboptimal concentrations of CSF. This enhancing effect was most probably not due to production of additional CSF in the cultures since it has been our experience that adherent exudate cells do not produce detectable CSF when challenged with LPS. The possibility that exposure to CSF might augment CSF production by LPS-stimulated exudate macrophages, however, has not been eliminated. This possibility also seems unlikely since the number of clones forming in response to the combination of submicrogram doses of LPS and suboptimal concentrations of CSF often exceeded that observed with optimal CSF doses (Fig. 5A). Therefore, the enhancing effect of LPS may be due to some other action of LPS rather than to endogenous CSF production. In this context, the enhancement may be related to the observations of Dienstman and Defendi (9) that a significant portion of the exudate macrophage population can be directly stimulated by LPS to enter the cell cycle. Although, as shown in our study, LPS alone is insufficient to permit a cloning response, it is possible that in the presence of suboptimal concentrations of CSF, LPS provides the necessary stimulus for these cells to enter the cell cycle while the CSF provides stimulation for sustained proliferation.

LPS in the presence of optimal or supraoptimal concentrations of CSF was found to suppress cloning of macrophage progenitor cells. This inhibition is not the result of a cytotoxic effect of the LPS. As with the enhancing effect of LPS, it is unclear whether this inhibition is due to a direct action of LPS on the progenitor cell or is mediated by some LPS-induced macrophage product. Three major factors which should be considered as possible inhibitors are E prostaglandins (19), tumor necrosis factor (36), and interferon (17). Addition of indomethacin, which is sufficient to inhibit prostaglandin production (28), failed to alter the inhibitory effect of LPS (Fig. 2). This indicated that prostaglandins, which can inhibit CSF-induced monopoiesis in vitro (19), were not responsible for the inhibitory effect of LPS in these experiments. Recently, Shah et al. (36) presented evidence suggesting that tumor necrosis factor can inhibit CSF-induced myelopoiesis in vitro. In a recent report from this laboratory (24), we presented evidence that CSF-cloned macrophages chal- 
lenged with LPS produce a cytotoxic factor with properties similar to serum-derived tumor necrosis factor. Addition of partially purified serum tumor necrosis factor (24) to the cultures, however, had no effect on the CSF-induced cloning response (data not shown). This indicated that the inhibitory effect of LPS in these experiments was probably not due to the production of tumor necrosis factor in the cultures. Interferon has been shown to have anti-proliferative activities for mammalian cells (15) and has been suggested to inhibit CSF-induced myelopoiesis in vitro (17). LPS is known to induce interferon production by macrophages (23), and we have recently reported that CSF-treated exudate macrophages produce enhanced levels of interferon when challenged with LPS (29). In preliminary experiments, addition to the cultures of antiserum prepared against murine type 1 interferon $(\mathrm{Na}$ tional Institute of Allergy and Infectious Diseases, Antiviral Substances Program) partially neutralized the inhibitory effect of LPS without affecting the normal cloning response to CSF. Although more extensive investigation of the possible role of interferon in this inhibitory effect of LPS is required, it is clear that the effects of LPS, either inhibitory or enhancing, are related to the dose of CSF to which the cells are exposed. With respect to interferon, it is important to note that a relationship does appear to exist between the effect of CSF as a macrophagestimulating agent and the results obtained in the present study. Exudate macrophages treated with at least $1,000 \mathrm{U}$ of CSF display a significantly enhanced responsiveness to LPS as measured by interferon production (29). Doses of CSF less than 1,000 units yielded less than significant enhancement (29). Viewed in this context, it is possible that in the presence of higher concentrations of CSF the exudate population responds to LPS in an activating fashion which precludes or inhibits proliferation, whereas LPS promotes a proliferative response in cultures exposed to suboptimal concentrations of CSF.

Regardless of the mechanism by which LPS either enhances or inhibits CSF-induced cloning of macrophage precursor cells, results obtained in this study indicate that lipid $A$ is probably the active portion of the LPS molecule in these effects. LPS neither enhanced nor inhibited the cloning response of progenitor cells from the $\mathrm{C} 3 \mathrm{H} / \mathrm{HeJ}$ mouse strain whose macrophages are genetically deficient in response to lipid A (11, $33,41,44)$. Also, both the enhancing and inhibitory effects of LPS on cells from genetically responsive mice could be either totally or partially neutralized by polymyxin $\mathrm{B}$, an antibiotic which binds to lipid A (31).

Although many questions remain to be re- solved regarding the alterations of in vitro monopoiesis by LPS, these results serve to reemphasize the relationship between the mononuclear phagocyte system and LPS in both the infected and healthy host. They clearly suggest that LPS is intimately involved in regulation of monopoiesis, both indirectly through stimulation of CSF production and by its effects on the CSF-responsive progenitor cells.

\section{ACKNOWLEDGMENTS}

We thank John Farrar, Terry Hoffeld, and Beda Stadler for their assistance in the preparation of this manuscript. We also acknowledge the excellent secretarial help of Sybil Ceja.

\section{LITERATURE CITED}

1. Alexander, P., and R. Evans. 1971. Endotoxin and double stranded RNA render macrophages cytotoxic. Nature (London) New Biol. 232:76-78.

2. Böhme, D. H., H. A. Schneider, and J. M. Lee. 1959. Some physiopathological parameters of natural resistance to infection in murine salmonellosis. J. Exp. Med. 110:9-24.

3. Bradley, S. G. 1979. Cellular and molecular mechanisms of action of bacterial endotoxins. Annu. Rev. Microbiol. 33:67-94.

4. Bradley, T. R., and D. Metcalf. 1966. The growth of mouse bone marrow cells in vitro. Aust. J. Exp. Biol. Med. Sci. 44:287-299.

5. Burgess, A. W., D. Metcalf, and S. M. Watt. 1978. Regulation of hemopoietic cell differentiation and proliferation. J. Supramol. Struct. 8:489-500.

6. Butler, R. C., A. M. Abdelnoor, and A. Nowotny. 1978. Bone marrow colony-stimulating factor and tumor resistance-enhancing activity of postendotoxin mouse sera. Proc. Natl. Acad. Sci. U.S.A. 75:2893-2896.

7. Chang, C. F., and M. Pollard. 1973. Effects of microbial flora on levels of colony stimulating factor in serum of irradiated CFW mice. Proc. Soc. Exp. Biol. Med. 144: 177-180.

8. Chervenick, P. A. 1972. Effect of endotoxin and postendotoxin plasma on in vitro granulopoiesis. J. Lab. Clin. Med. 79:1014-1020.

9. Dienstman, S. R., and V. Defendi. 1978. Necessary and sufficient conditions for recruitment of macrophages into the cell cycle. Exp. Cell Res. 115:191-199.

10. Doe, W. F., and P. M. Henson. 1978. Macrophage stimulation by bacterial lipopolysaccharides. I. Cytolytic effect on tumor target cells. J. Exp. Med. 148:544-556.

11. Doe, W. F., S. T. Yang, D. C. Morrison, S. J. Betz, and $P$. M. Henson. 1978. Macrophage stimulation by bacterial lipopolysaccharides. II. Evidence for differentiation signals delivered by lipid $\mathbf{A}$ and by a protein rich fraction of lipopolysaccharides. J. Exp. Med. 148:557568.

12. Eaves, A. C., and W. R. Bruce. 1974. In vitro production of colony-stimulating activity. I. Exposure of mouse peritoneal cells to endotoxin. Cell Tissue Kinet. 7:1930.

13. Gery, I., R. K. Gershon, and B. H. Waksman. 1972. Potentiation of the T-lymphocytes response to mitogens. I. The responding cell. J. Exp. Med. 136:128-142.

14. Glode, L. M., S. E. Mergenhagen, and D. L. Rosenstreich. 1977. Resistance of macrophages from $\mathrm{C} 3 \mathrm{H} /$ HeJ mice to the in vitro cytotoxic effects of endotoxin. J. Immunol. 119:162-166.

15. Gresser, I., J. De Maeyer-Guignard, M. G. Tovey, and E. De Maeyer. 1979. Electrophoretically pure mouse interferon exerts multiple biologic effects. Proc. 
Natl. Acad. Sci. U.S.A. 76:5308-5312.

16. Hadden, J. W., J. R. Sadlik, and E. M. Hadden. 1978. The induction of macrophage proliferation in vitro by a lymphocyte-produced factor. J. Immunol. 121:231238.

17. Hull, E. V., H. Schellekens, B. Lowenberg, and M. J. deVries. 1978. Influence of interferon preparations on the proliferative capacity of human and mouse bone marrow cells in vitro. Cancer Res. 38:911-914.

18. Kurland, J. I., and R. Bockman. 1978. Prostaglandin E production by human blood monocytes and mouse peritoneal macrophages. J. Exp. Med. 7:952-957.

19. Kurland, J., and M. A. S. Moore. 1977. Modulation of hemopoiesis by prostaglandins. Exp. Hematol. 5:357373.

20. Kurland, J. I., L. M. Pelus, P. Ralph, R. S. Bockman, and M. A. S. Moore. 1979. Induction of prostaglandin E synthesis in normal and neoplastic macrophages: role of colony-stimulating factor(s) distinct from effects on myeloid progenitor cell proliferation. Proc. Natl. Acad. Sci. U.S.A. 76:2326-2330.

21. MacVittie, T. J., and R. I. Walker. 1978. Endotoxininduced alterations in canine granulopoiesis: colonystimulating factor, colony-forming cells in culture and growth of cells in diffusion chambers. Exp. Hematol. 6: 613-618.

22. MacVittie, T. J., and R. I. Walker. 1978. Canine granulopoiesis: alterations induced by suppression of gramnegative flora. Exp. Hematol. 6:639-647.

23. Maehara, N., and M. Ho. 1977. Cellular origin of interferon induced by bacterial lipopolysaccharide. Infect. Immun. 15:78-83.

24. Männel, D. N., R. N. Moore, and S. E. Mergenhagen. 1980. Endotoxin-induced tumor cytotoxic factor, p. 141143. In D. Schlessinger (ed.), Microbiology-1980. American Society for Microbiology, Washington, D.C.

25. McIntire, F. C., H. W. Sievert, G. H. Barlow, R. A. Finley, and A. Y. Lee. 1967. Chemical physical and biological properties of a lipopolysaccharide from $E s c h$. erichia coli $\mathrm{K} 235$. Biochemistry 6:2363-2372.

26. Mizel, S. B., J. J. Oppenheim, and D. L. Rosenstreich. 1978. Characterization of lymphocyte activating factor

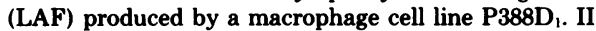
Biochemical characterization of LAF induced by activated T cells and LPS. J. Immunol. 120:1504-1508.

27. Moore, R. N., K. J. Goodrum, and L. J. Berry. 1976. Mediation of an endotoxin effect by macrophages. RES J. Reticuloendothel. Soc. 19:187-197.

28. Moore, R. N., R. Urbaschek, L. M. Wahl, and S. E. Mergenhagen. 1979. Prostaglandin regulation of colony-stimulating factor production by lipopolysaccharide-stimulated murine leukocytes. Infect. Immun. 26: 408-414.

29. Moore, R. N., S. N. Vogel, L. M. Wahl, and S. E. Mergenhagen. 1980. Factors influencing lipopolysaccharide-induced interferon production, p. 131-134. In D. Schlessinger (ed)., Microbiology-1980. American Society for Microbiology, Washington, D.C

30. Morland, B., and J. Morland. 1978. Selective induction of lysosomal enzyme activities in mouse peritoneal macrophages. RES J. Reticuloendothel. Soc. 23:469-477.

31. Morrison, D. C., and D. M. Jacobs. 1976. Binding of polymyxin B to the lipid A protein of bacterial lipopoly- saccharide. Immunochemistry 133:813-818.

32. Pabst, M. J., and R. B. Johnston, Jr. 1980. Increased production of superoxide anion by macrophages exposed in vitro to muramyl dipeptide or lipopolysaccharide. J. Exp. Med. 151:101-114.

33. Peavy, D. L., R. E. Baughn, and D. M. Musher. 1978. Strain-dependent cytotoxic effects of endotoxin for mouse peritoneal macrophages. Infect. Immun. 21:310 319.

34. Pluznik, D. H., and L. Sachs. 1966. The induction of clones of normal mast cells by a substance from conditioned medium. Exp. Cell Res. 43:533-563.

35. Quesenberry, P., A. Morley, F. Stohman, Jr., K. Richard, D. Howard, and M. Smith. 1972. Effect of endotoxin on granulopoiesis and colony-stimulating factor N. Engl. J. Med. 286:227-232.

36. Shah, R. G., S. Green, and M. A. S. Moore. 1978. Colony-stimulating and inhibiting activities in mouse serum after Corynebacterium parvum-endotoxin treatment. RES J. Reticuloendothel. Soc. 23:29-41.

37. Shands, J. W., Jr., D. L. Peavy, B. J. Gormus, and J. McGraw. 1974. In vitro and in vivo effects of endotoxin on mouse peritoneal cells. Infect. Immun. 9:106-112.

38. Stanely, E. R., M. Cifone, P. M. Heard, and V. Defendi. 1976. Factors regulating macrophage production and growth: identity of colony-stimulating factor and macrophage growth factor. J. Exp. Med. 143:631-647.

39. Stewart, C. C., and H. Lin. 1978. Macrophage growth factor and its relationship to colony stimulating factor. RES J. Reticuloendothel. Soc. 23:269-285.

40. Trudgett, A., T. A. McNeill, and M. Killen. 1973. Gran ulocyte-macrophage precursor cell and colony-stimulating factor responses of mice infected with Salmonella typhimurium. Infect. Immun. 8:450-455.

41. Vogel, S. N., S. T. Marshall, and D. L. Rosenstreich. 1979. Analysis of the effects of lipopolysaccharide on macrophages: differential phagocytic responses of $\mathrm{C} 3 \mathrm{H} /$ $\mathrm{HeN}$ and $\mathrm{C} 3 \mathrm{H} / \mathrm{HeJ}$ macrophages in vitro. Infect. Immun. 25:328-336.

42. Waheed, A., and R. K. Shadduck. 1979. Purification and properties of $\mathrm{L}$ cell-derived colony-stimulating factor. J. Lab. Clin. Med. 94:180-194.

43. Wahl, L. M., C. E. Olsen, A. L. Sandberg, and S. E. Mergenhagen. 1977. Prostaglandin regulation of macrophage collagenase production. Proc. Natl. Acad. Sci. U.S.A. 74:4955-4958.

44. Wahl, L. M., D. L. Rosenstreich, L. M. Glode, A. L. Sandberg, and S. E. Mergenhagen. 1979. Defective prostaglandin synthesis by $\mathrm{C} 3 \mathrm{H} / \mathrm{HeJ}$ mouse macrophages stimulated with endotoxin preparations. Infect. Immun. 23:8-13.

45. Wahl, L. M., S. M. Wahl, and J. B. McCarthy. 1980 Adjuvant activation of macrophage functions, p. 491504. In E. R. Unanue and A. S. Rosenthal (ed.), Macrophage regulation of immunity. Academic Press, Inc., New York.

46. Wahl, L. M., S. M. Wahl, S. E. Mergenhagen, and G. R. Martin. 1974. Collagenase production by endotoxin activation macrophages. Proc. Natl. Acad. Sci. U.S.A. 71:3598-3601.

47. Weinberg, J. B., H. A. Chapman, Jr., and J. B. Hibbs. 1978. Characterization of the effects of endotoxin on macrophage tumor cell killing. J. Immunol. 121:72-80. 